Journal of

Molecular Microbiology

and Biotechnology
DOI: $\underline{10.1159 / 000353208}$
Published online: September 6, 2013

\title{
Production of Hesperetin Using a Covalently Multipoint Immobilized Diglycosidase from Acremonium sp. DSM24697
}

\author{
Lucrecia Piñuel $^{a} \quad$ Javier D. Breccia ${ }^{a} \quad$ Jose M. Guisán ${ }^{b}$ Fernando López-Gallego ${ }^{b}$ \\ aINCITAP-CONICET Facultad Ciencias Exactas y Naturales, Universidad Nacional de La Pampa (UNLPam), \\ Santa Rosa, Argentina; ${ }^{\mathrm{b}}$ Departamento de Biocatálisis, Instituto de Catálisis y Petroleoquímica-CSIC, Madrid, Spain
}

\section{Key Words}

Biotransformation · Biocatalysis · Hesperidin · Flavonoids .

Citrus by-products

\begin{abstract}
The diglycosidase a-rhamnosyl- $\beta$-glucosidase (EC 3.2.1.168) from the fungus Acremonium sp. DSM24697 was immobilized on several agarose-based supports. Covalent multipoint immobilization onto glyoxyl-activated agarose was selected as the more stable preparation at high concentration of dimethyl sulfoxide (DMSO) and high temperature. The optimal conditions for the immobilization process involved an incubation of the enzyme with agarose beads containing $220 \mu \mathrm{mol}$ of glyoxyl groups per gram at $\mathrm{pH} 10$ and $25^{\circ} \mathrm{C}$ for $24 \mathrm{~h}$. The hydrolysis of hesperidin carried out in $10 \% \mathrm{v} / \mathrm{v}$ DMSO at $60^{\circ} \mathrm{C}$ for $2 \mathrm{~h}$ reached $64.6 \%$ substrate conversion and a specific productivity of $2.40 \mathrm{mmol} \mathrm{h}^{-1} \mathrm{~g}^{-1}$. Under these conditions, the process was performed reutilizing the catalyst for up to 18 cycles, maintaining $>80 \%$ of the initial activ-

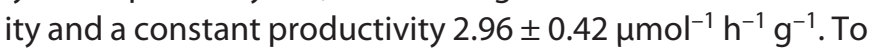
the best of our knowledge, such productivity is the highest achieved for hesperetin production through an enzymatic approach.

(c) 2013 S. Karger AG, Basel
\end{abstract}

(C) 2013 S. Karger AG, Basel

$1464-1801 / 13 / 0236-0410 \$ 38.00 / 0$
Flavone glycosides are one of the most abundant secondary metabolites in citrus species. These molecules impact on almost every citrus fruit's production and processing; for instance, they contribute to the bitter taste and also to juice clouding [Manthey and Grohmann, 1996]. Deglycosylation of different flavone glycosides is a challenge in food technology for debittering and clarifying fruit juices [Genovés et al., 2005; Hemingway et al., 1999; Wang et al., 2001]. On the other hand, several biological activities have been reported for the diverse backbones (2-phenyl-1,4-benzopyrone) of unglycosylated flavones [Benavente-García et al., 1997; Di Majo et al., 2005]. For instance, hesperetin, the aglycone of hesperidin, showed analgesic, anti-inflammatory and antioxidant properties, and it can also be used as synthon for the production of dyes and sweeteners [Di Majo et al., 2005].

Structurally, the flavonoid hesperidin is formed by rutinose (6-O- $\alpha$-L-rhamnopyranosyl- $\beta$-D-glucopyranoside) linked to the aglycone hesperetin (fig. 1). There are few bioprocesses that efficiently hydrolyze hesperidin to yield hesperetin [Mandalari et al., 2006; Scaroni et al., 2002]. Most of them involve sequential steps catalyzed by at least two monoglycosidases - $\alpha$-L-rhamnosidase (EC 3.2.1.40) and $\beta$-glucosidase (EC 3.2.1.21) - to remove the residues

\section{KARGER}

E-Mail karger@karger.com

www.karger.com $/ \mathrm{mmb}$
Javier D. Breccia

INCITAP-CONICET Facultad Ciencias Exactas y Naturales

Universidad Nacional de la Pampa (UNLPam)

Av. Uruguay 151, Santa Rosa 6300 (Argentina)

E-Mail javierbreccia@gmail.com 
Fig.1. Pathways for enzymatic deglycosylation of hesperidin to yield hesperetin: via hesperetin-7-O-glucoside by two specific monoglycosidases, $\alpha$-rhamnosidase (EC 3.2.1.40) and $\beta$-glucosidase (EC 3.2.1.21), and via one-step deglycosylation through aRßGl (EC 3.2.1.168).

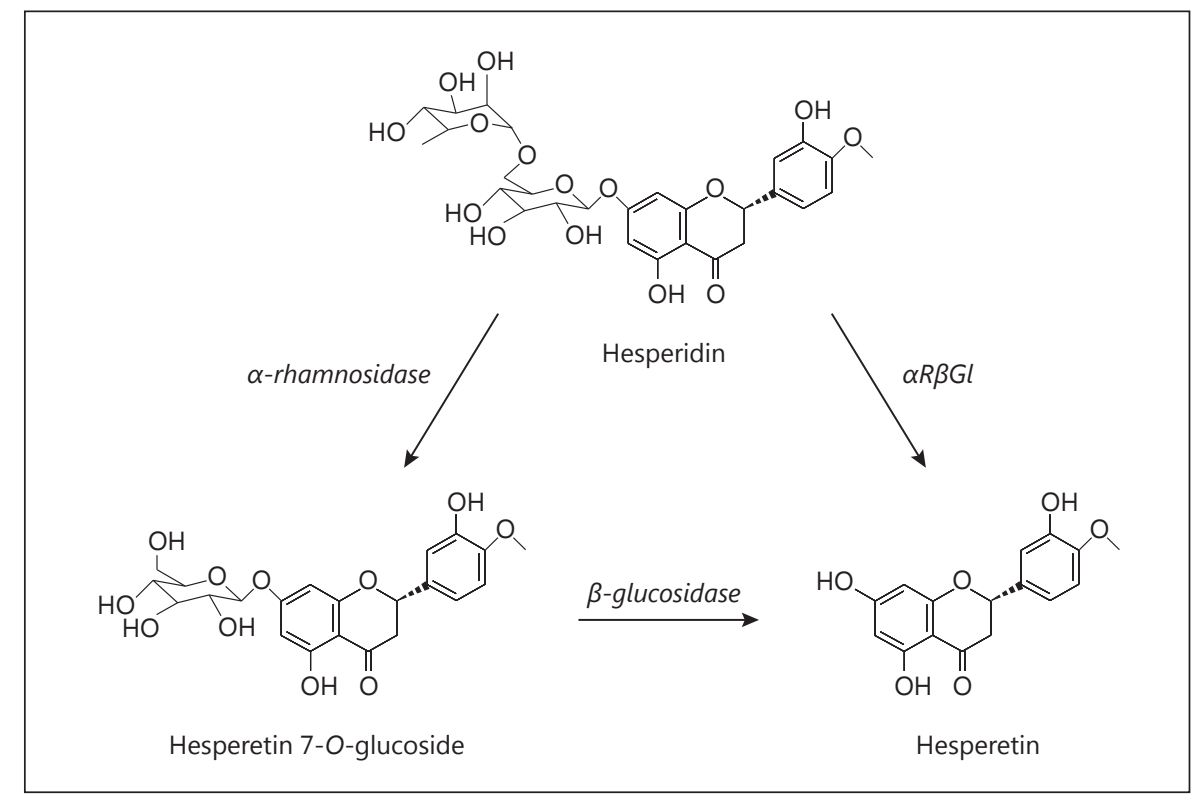

of rhamnose and glucose, respectively (fig. 1). Recently, a novel diglycosidase from Acremonium sp. DSM24697 able to deglycosylate hesperidin in a single step, rendering rutinose and hesperetin as reaction products, was described. This enzyme, $\alpha$-rhamnosyl- $\beta$-glucosidase $(\alpha R \beta G l$; EC 3.2.1.168), is a distinctive endoglycosidase specific for 7-O-rutinosilate flavonoids (fig. 1) [Mazzaferro et al., 2010]. It also enables the transglycosylation of rutinosyl units using the flavonoids hesperidin or hesperidin methyl chalcone as rutinose donors, which are abundant and inexpensive by-products of the citrus industry [Mazzaferro et al., 2012]. The resulting rutinosyl derivatives have potential application in the pharmaceutical as well as the food industry [Mazzaferro and Breccia, 2011, 2012].

Biotransformations are optimized in order to simplify the processes and, depending on the characteristics of the biocatalyst, immobilization could be a convenient approach, especially for those enzymes that support harsh physicochemical conditions during immobilization and do not require cofactors for the catalysis [Ribeiro, 2011; Sheldon, 2007]. Covalent multipoint attachment on porous supports has been a suitable system for many enzymes, promoting protein stabilization [Mateo et al., 2005]. This work deals with the development of a stable preparation of $\alpha R \beta G \mathrm{Gl}$ by covalent multipoint immobilization, focusing on the organic phase catalysis for hesperetin production.

Enzymatic Hesperetin Production

\section{Results and Discussion}

\section{Immobilization of $\alpha R \beta G l$}

The immobilization of $\alpha \mathrm{R} \beta \mathrm{Gl}$ was designed to produce hesperetin in one single enzymatic process with the possibility of recycling the fungal biocatalyst as much as possible (fig. 1). To select an adequate immobilization procedure, the enzyme $\alpha \mathrm{R} \beta \mathrm{Gl}$ was attached to agarose-based supports using four different ligands (table 1). It was quantitatively immobilized on the carrier containing nickel ions $\left(\mathrm{Ag}_{-} \mathrm{Ni}^{2+}\right)$, but was inactive on the support. Since this enzyme was reported as a prone oxidation protein, the inactivation on $\mathrm{Ag}-\mathrm{Ni}^{2+}$ might be due to metal catalyzed oxidation or an improper position of the biocatalyst on the support [Piñuel et al., 2011]. In contrast, the reversi-ble immobilization on agarose activated with ethylenediamine (Ag-A) showed a lower yield (37.8\%). When this preparation was covalently cross-linked to make the attachment irreversible, the yield improved to $65 \%$ and the immobilization efficiency dropped 55\%, probably due to the known deleterious effect of glutaraldehyde (table 1) [Reshmi and Sugunan, 2012]. The same immobilization chemistry, ionic absorption followed by glutaraldehyde cross-linking, was inefficient on agarose coated with polyethylenimine (Ag-PEI). Ag-PEI immobilized $>90 \%$ of the loaded protein; however, the activity exhibited on the support was vastly reduced $(>80 \%)$ after cross-linking with glutaraldehyde. A comparable phenomenon was previously described when the enzyme was 


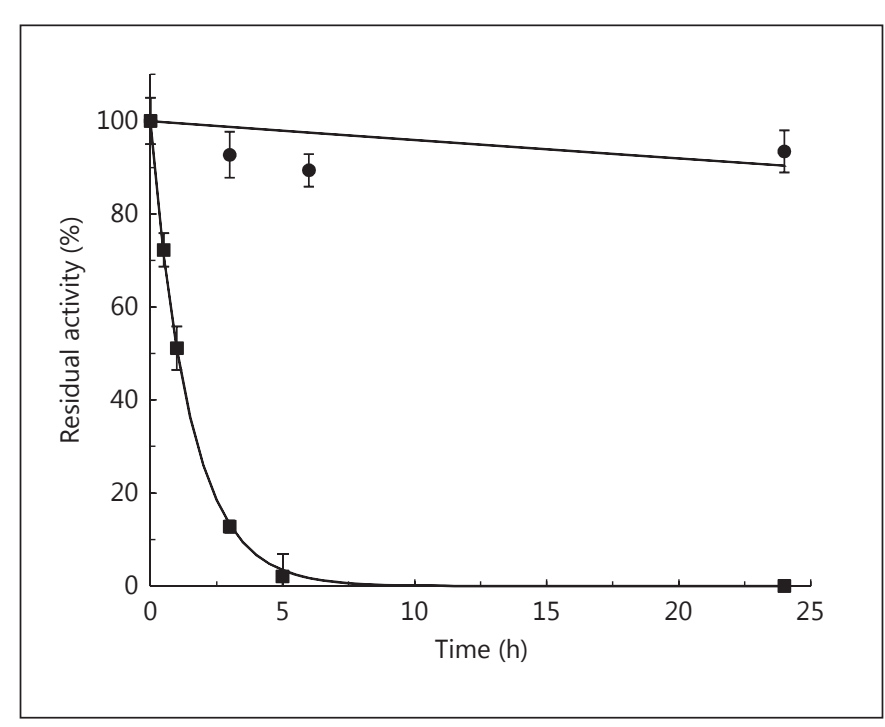

Fig. 2. The stability of soluble $\alpha R \beta G$ lincubated in $50 \% \mathrm{v} / \mathrm{v}$ DMSO at $25^{\circ} \mathrm{C}(\bullet)$ and $50^{\circ} \mathrm{C}(\boldsymbol{\square})$. The measurements of residual activity were performed after removing the solvent DMSO. The $100 \%$ activity corresponds to samples without DMSO containing 1.2 $\mathrm{U} / \mathrm{ml}$.

immobilized on chitosan beads coated with PEI and cross-linked with glutaraldehyde [Piñuel et al., 2011]. On the other hand, unipunctual covalent attachment to cyanogen bromide agarose (Ag-CB) and multipunctual attachment to glyoxyl agarose (Ag-G) was performed through the $\mathrm{N}$-terminal and lysine residues, respectively. The immobilization yield was significantly higher for AgCB. Nonetheless, both covalent derivatives exhibited similar immobilization efficiencies of around 64\%, which surpassed the other procedures assayed as well as those previously reported (18\% efficiency) for cross-linked PEI-chitosan beads of $1.67 \pm 0.99 \mathrm{~mm}$ in diameter (table 1) [Piñuel et al., 2011].

\section{Stability of $\alpha R \beta G l$ Preparations}

The polar aprotic solvent dimethyl sulfoxide (DMSO) is miscible in water and, at low concentration $(<5 \% \mathrm{v} / \mathrm{v})$, favored the catalysis of $\alpha R \beta G$ l by increasing the solubility of the substrate hesperidin [Mazzaferro et al., 2012]. Hence, the stability of the soluble enzyme was assessed by incubating it at high concentrations of the cosolvent $(50 \% \mathrm{v} / \mathrm{v} \mathrm{DMSO})$ at two different temperatures and measuring the residual activity in the absence of DMSO (fig. 2). In this condition, the soluble enzyme was highly stable at low temperature $\left(25^{\circ} \mathrm{C}\right)$ with an estimated half-

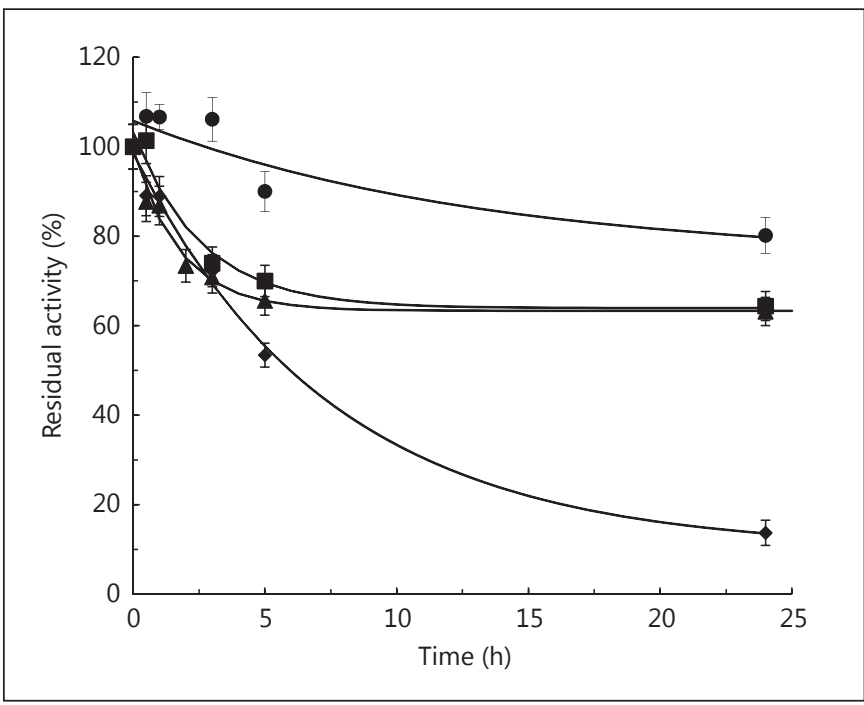

Fig. 3. The time course inactivation of different immobilized preparations of $\alpha \mathrm{R} \beta \mathrm{Gl}$ in a medium containing $50 \% \mathrm{v} / \mathrm{v} \mathrm{DMSO}$ at $\mathrm{pH}$ 5.0 and $40^{\circ} \mathrm{C}$ : soluble enzyme $(\boldsymbol{\Delta}), \operatorname{Ag}-\mathrm{G}(\bullet), \mathrm{Ag}-\mathrm{CB}(\bullet)$ and Ag-A (ם) cross-linked with glutaraldehyde. The $100 \%$ activity corresponds to samples without DMSO containing $0.83 \mathrm{U} / \mathrm{ml}$ for the soluble enzyme and $0.60,0.79$ and $0.39 \mathrm{U} / \mathrm{g}$ for the immobilized preparations, respectively.

Table 1. Immobilization of $\alpha \mathrm{R} \beta \mathrm{Gl}$ on four different agarose derivatives

\begin{tabular}{llllc}
\hline Support & YI, \% & $\begin{array}{l}\text { Immobilized } \\
\text { activity, U/g }\end{array}$ & $\begin{array}{l}\text { Expressed } \\
\text { activity, U/g }\end{array}$ & EI, \% \\
\hline Ag-G & 60.6 & 0.93 & 0.61 & 65.4 \\
Ag-CB & 90.3 & 1.25 & 0.79 & 62.9 \\
Ag-Ni+2 $^{+25}$ & 97.6 & 1.03 & ND & 0 \\
Ag-A $_{\text {Ag-A }}^{\text {a }}$ & 37.8 & 0.40 & 0.13 & 32.8 \\
Ag-PEI $^{\text {a }}$ & 65.6 & 0.86 & 0.39 & 45.4 \\
\hline
\end{tabular}

All data are mean values of 3 separate experiments (error value $<5 \%)$. YI and EI are defined in equations 1 and 2 . ND = Not detected.

${ }^{\text {a }}$ Derivatives cross-linked with $0.5 \%$ v/v glutaraldehyde.

life $>160 \mathrm{~h}$, but it was exponentially unfolded at $50^{\circ} \mathrm{C}$ $\left(\mathrm{t}_{1 / 2}=1 \mathrm{~h}\right)$. The destabilizing effect of protein structure by increment of the hydrophobic character of the medium at high DMSO concentration and temperature is a known phenomenon [Arakawa et al., 2007]. As a result, the stability of three $\alpha R \beta G$-insoluble preparations (Ag-CB, Ag-A + glutaraldehyde and Ag-G) was evaluated under $50 \% \mathrm{v} / \mathrm{v}$ aqueous solution of DMSO at $40^{\circ} \mathrm{C}$. Figure 3 
Table 2. Reaction media engineering for hesperetin production using $a \mathrm{R} \beta \mathrm{Gl}$ immobilized on Ag-G

\begin{tabular}{llllll}
\hline $\begin{array}{l}\text { Cosolvent, } \\
\%\end{array}$ & $\begin{array}{l}\text { Reaction } \\
\text { temperature, } \\
{ }^{\circ} \mathrm{C}\end{array}$ & $\begin{array}{l}\text { Substrate, } \\
\mathrm{mM}\end{array}$ & $\begin{array}{l}\text { Product, } \\
\mathrm{mM}\end{array}$ & $\begin{array}{l}\text { Substrate } \\
\text { conversion, } \\
\%\end{array}$ & $\begin{array}{l}\text { Productivity } \\
\mu \mathrm{mol} \mathrm{h}^{-1} \mathrm{~g}^{-1}\end{array}$ \\
\hline 10 & 50 & 0.52 & 0.35 & 67.9 & $2.82 \pm 0.07$ \\
10 & 60 & 0.52 & 0.34 & 64.6 & $3.36 \pm 0.19$ \\
50 & 40 & 5 & 3.63 & 72.4 & $3.02 \pm 0.01$ \\
75 & 25 & 15 & 0 & 0 & 0 \\
75 & 40 & 15 & 0 & 0 & 0 \\
$40: 20^{\mathrm{b}}$ & 40 & 10 & 1.19 & 11.9 & $0.99 \pm 0.04$ \\
\hline
\end{tabular}

\footnotetext{
a Productivity per gram of support; the preparation contained $1.5 \mathrm{mg}$ of pure $\alpha \mathrm{R} \beta \mathrm{Gl}$ per gram of solid carrier.

${ }^{\mathrm{b}}$ Corresponding to $40 \% \mathrm{v} / \mathrm{v}$ DMSO and $20 \% \mathrm{v} / \mathrm{v} 2$-butanone.
}

shows that Ag-G resulted in the more stable catalyst (estimated $t_{1 / 2}>70 \mathrm{~h}$ ), the Ag-A preparation showed a similar profile to the soluble protein (estimated $t_{1 / 2}>25 \mathrm{~h}$ ), while the Ag-CB $\left(\mathrm{t}_{1 / 2}=6 \mathrm{~h}\right)$ was the more unstable preparation. This implies that this enzyme, as well as several other enzymes reported, was highly stabilized by multipoint covalent immobilization with a half-life approximately three times higher in comparison with the soluble protein [Mateo et al., 2006]. Although knowledge of the primary and secondary structure of $\alpha R \beta G l$ is limited, the stabilization achieved by immobilization on Ag-G would suggest an important number of lysine residues fairly exposed in the protein surface and ready to react with the glyoxyl groups of the support [Mazzaferro et al., 2010].

The immobilization procedure onto Ag-G can be optimized by adjusting different variables, such as the time under alkaline conditions and the density of reactive groups on the support [Mateo et al., 2006]. The immobilization protocol was modified by changing the time of incubation at $\mathrm{pH} 10$ and the stability of the resulting preparations was then evaluated in $50 \% \mathrm{v} / \mathrm{v}$ DMSO at $50^{\circ} \mathrm{C}$. In all cases the immobilization yield was around $60 \%$, but the stability of the preparation varied significantly. For 2 and $7 \mathrm{~h}$ of incubation at $\mathrm{pH} 10$, the resulting preparations showed halflives between 3 and $4 \mathrm{~h}$, while the preparation incubated for $24 \mathrm{~h}$ doubled those values (data no shown). The longer time of incubation seems to endorse a larger number of covalent bounds and consequently an increment in the rigidity of the peptide, rendering higher stability in the presence of solvent and high temperature [Pedroche et al., 2007]. These results are in agreement with the lower stability exhibited by the Ag-CB derivative, where the peptide is

Enzymatic Hesperetin Production attached unipunctually to the support (fig. 3) [Mateo et al., 2005]. Furthermore, the density of reactive groups on the support surface was assessed with Ag-G preparations containing 150 or $220 \mu \mathrm{mol}$ of glyoxyl groups per gram. The half-life of the resulting derivatives incubated in $50 \% \mathrm{v} / \mathrm{v}$ DMSO at $50^{\circ} \mathrm{C}$ increased 4 -fold for the support with a higher density of glyoxyl groups (data not shown). Therefore, the matrix with $220 \mu \mathrm{mol}$ of glyoxyl groups per gram and the immobilization protocol with an incubation time at $\mathrm{pH} 10.0$ of $24 \mathrm{~h}$ were applied in further experiments.

\section{Engineering the Reaction Media to Improve \\ Hesperetin Yield}

The Ag-G aR $\beta$ Gl preparation was used to hydrolyze the 7-O-rutinosylated flavonoid, hesperidin, in several homogeneous systems (fig. 1; table 2). The biotransformation was carried out in the presence of different concentrations of DMSO to overcome the low solubility of hesperidin in water $(0.32 \mathrm{mM})$ [Mazzaferro et al., 2010]. To increase the soluble substrate concentration, $50 \% \mathrm{v} / \mathrm{v}$ DMSO was used, dissolving up to $5 \mathrm{mM}$ of hesperidin. Nevertheless, at a high cosolvent concentration, as well as high temperature, the environment becomes deleterious, even for the immobilized preparation of the catalyst. Therefore, the reaction was carried out at a lower temperature $\left(40^{\circ} \mathrm{C}\right)$, obtaining $3.63 \mathrm{mM}$ of hesperetin. Although this product concentration was 10 -fold higher than that obtained in $10 \% \mathrm{v} / \mathrm{v}$ DMSO, the operational cycle at $50 \% \mathrm{v} / \mathrm{v}$ DMSO took $24 \mathrm{~h}$ to reach the plateau of maximum substrate conversion (72\%), drastically reducing the productivity of the process (table 2). The conversion value $(\sim 70 \%)$ might be due to product inhibition issues, as has been reported elsewhere for other glycosidases [Ellenrieder et al., 1998]. In this way, other solvents (DMF, acetonitrile, ethyl acetate) were also evaluated, but hesperidin was not as soluble as in DMSO. For instance, the mixture of DMSO and 2-butanone dissolved up to 10 $\mathrm{mM}$ of hesperidin, but the substrate conversion was low (12\%), probably due to a deleterious effect of the cosolvent mixture on the biocatalyst. Although higher concentrations of DMSO increase hesperidin solubility up to 15 $\mathrm{mM}$, it was also detrimental to the hydrolytic activity of the enzyme, even at a lower temperature $\left(25^{\circ} \mathrm{C}\right.$; table 2$)$. The preferential hydration of proteins that DMSO provokes at low concentrations is transposed to preferential interaction at high temperatures and high concentrations, with the consequent protein unfolding, and this phenomenon was not overcome with the insoluble preparation of $\alpha R \beta \mathrm{Gl}$ (table 2) [Arakawa et al., 2007]. Considering the instability generated by the increment of cosol- 


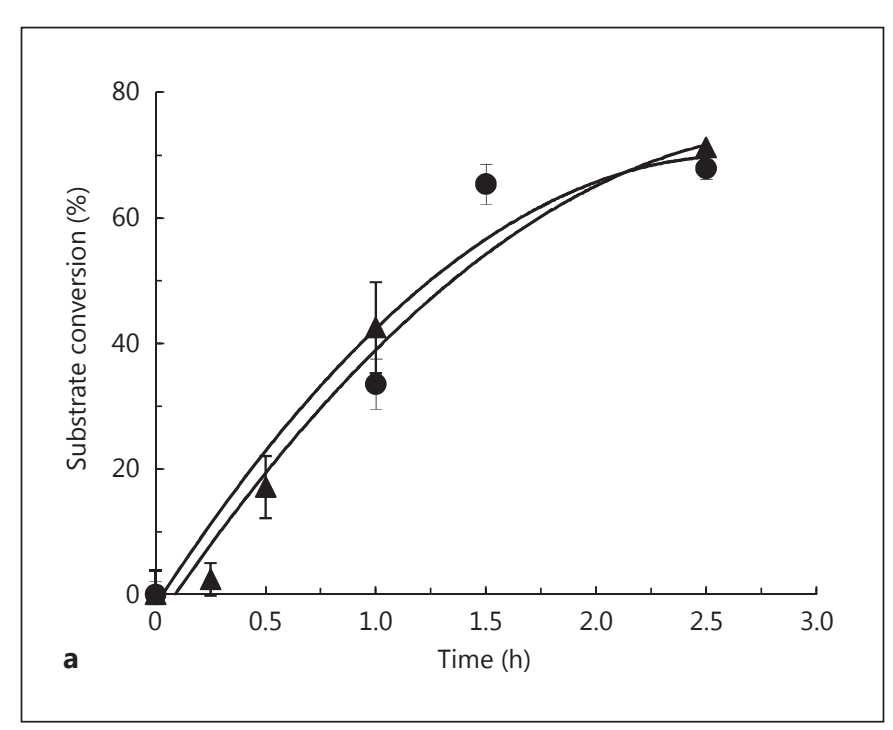

Fig. 4. Enzymatic production of hesperetin with $\alpha R \beta G \mathrm{Gl}$ Ag-G derivative in a reaction medium containing $0.52 \mathrm{mM}$ of hesperidin and $10 \% \mathrm{v} / \mathrm{v} \mathrm{DMSO}$ at $\mathrm{pH} 5$ and $60^{\circ} \mathrm{C}$. a Reaction courses catalyzed by soluble $(\mathbf{A})$ and immobilized ( $)$ enzyme. b Reusability of the

vent concentration, the temperature was raised up to $60^{\circ} \mathrm{C}$ in a medium with $10 \% \mathrm{v} / \mathrm{v}$ DMSO. This system presented a higher productivity $\left(3.36 \mu \mathrm{mol} \mathrm{h}{ }^{-1} \mathrm{~g}^{-1}\right)$, slightly elevated compared to the productivity obtained at $50^{\circ} \mathrm{C}$.

\section{Production of Hesperetin}

In this context, high concentrations of the cosolvent yielded a higher concentration of hesperetin, but a direct trade-off was established between production, productivity and enzyme destabilization. Hence, the process of hesperidin biotransformation was carried out using the free form and the $\mathrm{Ag}-\mathrm{G} \alpha \mathrm{R} \beta \mathrm{Gl}$ in a medium containing $10 \% \mathrm{v} / \mathrm{v}$ $\mathrm{DMSO}$, at $60^{\circ} \mathrm{C}$. Although the time-course biotransformation showed a maximum substrate conversion of around $68 \%$ after $2-2.5 \mathrm{~h}$ for both soluble and immobilized enzyme, the Ag-G aR $\beta$ Gl preparation allowed the reutilization of the catalyst (fig. 4). Twenty cycles of hesperidin hydrolysis of $2 \mathrm{~h}$ at $60^{\circ} \mathrm{C}$ were performed with the immobilized enzyme. The productivity was constant after 15 cycles of reutilization $\left(2.96 \pm 0.42 \mu \mathrm{mol}^{-1} \mathrm{~h}^{-1} \mathrm{~g}^{-1}\right)$ and it only dropped by $\sim 20 \%$ after 20 operational cycles (fig. 4 b).

Most of the reported enzymatic systems for hesperidin hydrolysis were performed using soluble biocatalysts (table 3). The hesperetin concentration yielded by the Ag-G $\alpha R \beta G l$ system was around 3.5 times higher than the system catalyzed by pectinase 62L (a bulk enzyme preparation), and 16-fold lower than a heterogeneous system that used

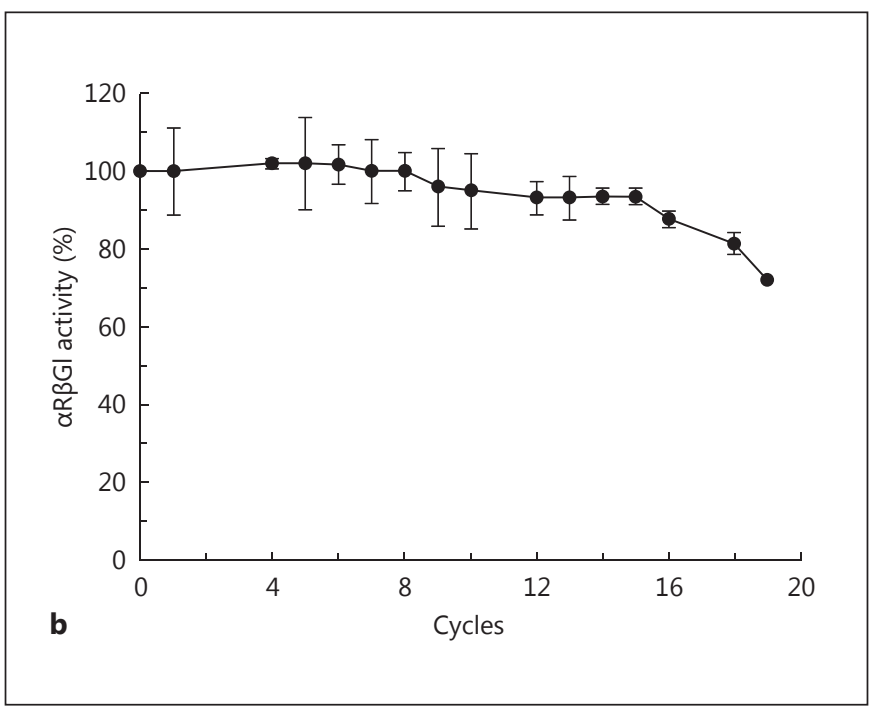

biocatalyst preparation assessed in 20 cycles of the 2-hour reaction. The $100 \%$ activity corresponds to $0.72 \mathrm{U} / \mathrm{ml}$ and $0.55 \mathrm{U} / \mathrm{g}$ for soluble and immobilized enzyme, respectively.

supersaturated suspensions of hesperidin $(16 \mathrm{mM})$ as the substrate. However, the specific productivities were $~ 25-$ and 37 -fold lower, respectively, than the specific productivity found for the system herein presented (table 3) [Mandalari et al., 2006; Scaroni et al., 2002]. Moreover, an additional advantage of the reaction catalyzed by $\mathrm{Ag}-\mathrm{G}$ $\alpha R \beta G l$, besides the possibility of recycling it, is that it also coproduced another highly valuable product, the disaccharide rutinose. This is in contrast to the sequential enzymatic mechanisms of deglycosylation involving two monoglycosidases, where the aglycone productivity becomes a more complex biotransformation composed of five chemical species (the substrate, rhamnose, glucose, the glucosylated aglycone and the aglycone) [Orrillo et al., 2007; Scaroni et al., 2002; Spagna et al., 2002]. Recently, a one-step process for rutin deglycosylation using a thermophile promiscuous $\beta$-glucosidase and releasing quercetin and rutinose was also reported. In such a system, the specific productivity of quercetin was lower than the system herein described for hesperidin (table 3) [Nam et al., 2012].

\section{Concluding Remarks}

An immobilized $\alpha R \beta G$ l preparation was developed for hesperetin production from a low-cost byproduct of the citrus industry (hesperidin). The immobilization was op- 
Table 3. Comparison of different systems for the enzymatic deglycosylation of three flavonoid glycosides

\begin{tabular}{|c|c|c|c|c|c|}
\hline Flavonoid & $\begin{array}{l}\text { Substrate } \\
\text { concentration, } \mathrm{mM}\end{array}$ & Enzyme & $\begin{array}{l}\text { Substrate } \\
\text { conversion, \% }\end{array}$ & $\begin{array}{l}\text { Specific productivity } \\
\mathrm{mmol} \mathrm{h}^{-1} \mathrm{~g}^{-1}\end{array}$ & References \\
\hline Rutin & 10 & $\begin{array}{l}\text { promiscuous } \\
\beta \text {-glucosidase }\end{array}$ & 65 & 1.04 & [Nam et al., 2012] \\
\hline \multirow[t]{2}{*}{ Naringin } & 172 & rhamnosidase glucosidase & 80 & 28.21 & [Ellenrieder et al., 1998 \\
\hline & 1.7 & rhamnosidase & 91 & $6.45^{b}$ & [Chang et al., 2011] \\
\hline \multirow[t]{3}{*}{ Hesperidin } & 16 & rhamnosidase glucosidase & 35 & 0.09 & [Scaroni et al., 2002] \\
\hline & 0.2 & pectinase $62 \mathrm{~L}$ & 48 & 0.06 & [Mandalari et al., 2006] \\
\hline & 0.52 & $\alpha \mathrm{R} \beta \mathrm{Gl}$ & 64.6 & 2.40 & this work \\
\hline
\end{tabular}

a Specific productivity was defined as the aglycone produced in mmol per hour per gram of protein. In the case of $\alpha \mathrm{R} \beta \mathrm{Gl}$ it was estimated per gram of protein contained in the support.

$\mathrm{b}$ Production of the intermediate compound prunin (glucosylated naringenin).

timized rendering a highly stable biocatalyst able to perform the biotransformation in harsh conditions $(10 \% \mathrm{v} / \mathrm{v}$ DMSO and $60^{\circ} \mathrm{C}$ ). The heterogeneous catalyst, working in batch mode for 20 cycles, only lost $20 \%$ activity and reached specific productivity values of $2.40 \mathrm{mmol} \mathrm{h}^{-1} \mathrm{~g}^{-1}$. Hence, a promising process for the hydrolysis of hesperidin has emerged, which could also be applied for other 7-O-rutinosilated flavonoids.

\section{Experimental Procedures}

\section{Materials}

Agarose 10 BCL was purchased from Agarose Bead Technologies (Madrid, Spain). Cyanogen bromide-activated Sepharose 4B (Ag-CB) was purchased from Pharmacia Fine Chemicals (Uppsala, Sweden). Epichlorohydrin, ethylenediamine, PEI (MW 25 $\mathrm{kDa}$ ), glutaraldehyde $25 \% \mathrm{w} / \mathrm{v}$, DMSO, hesperidin, hesperetin and hesperidin methyl chalcone were purchased from Sigma (St. Louis, Mo., USA). All other chemicals were of analytical grade.

\section{Strain, Growth Conditions and Protein Purification}

Acremonium sp. DSM24697 was cultured using hesperidin as the carbon source and the enzyme was purified following the procedure previously described by Mazzaferro et al. [2010].

\section{Activation of Agarose 10 BCL with Glyoxyl Groups (Ag-G)}

This matrix was prepared by reaction of hydroxyl groups forming the agarose $10 \mathrm{BCL}$ to either glycidol or epichlorohydrin. Agarose was activated with glycidol according to the protocol described by Guisán [1988], while to activate the agarose with epichlorohydrin, $10 \mathrm{~g}$ of agarose $10 \mathrm{BCL}$ were suspended in $44 \mathrm{ml}$ of water, $16 \mathrm{ml}$ of acetone, $3.28 \mathrm{~g}$ of $\mathrm{NaOH}, 0.2 \mathrm{~g}$ of $\mathrm{NaBH}_{4}$ and $11 \mathrm{ml}$ of epichlorohydrin [Mateo et al., 2010]. The suspension was stirred mildly for $16 \mathrm{~h}$ and washed with an excess of water. The epoxy groups were hydrolyzed in the presence of $0.5 \mathrm{M}$ of sulfuric acid $\left(12 \mathrm{~h}, 25^{\circ} \mathrm{C}\right)$, resulting in a surface activated with vicinal diols that would finally be oxidized with sodium periodate. The quantification of glyoxyl groups on the resulting matrices was performed by determining the not consumed periodate after the oxidation step. The remaining periodate was determined with a $10 \% \mathrm{KI}$ solution under alkaline conditions.

Agarose Activated with Primary Amine Groups (Ag-A)

Monoaminoethyl-N-ethyl-agarose was prepared from glyoxyl agarose according to Fernandez-Lafuente et al. [1993].

Agarose Activated with PEI (Ag-PEI)

The glyoxyl-agarose 4 BCL support was coated with PEI of average molecular weight $25 \mathrm{kDa}$. The support (5 g) was suspended in $50 \mathrm{ml}$ of $10 \% \mathrm{w} / \mathrm{v}$ PEI at $\mathrm{pH} 11.0$. The suspension was kept under mild stirring at $25^{\circ} \mathrm{C}$ for $2 \mathrm{~h}$. Then, the support was reduced by adding solid sodium borohydride to a final concentration of 10 $\mathrm{mg} / \mathrm{ml}$ and was left under mild stirring for $30 \mathrm{~min}$ at $4^{\circ} \mathrm{C}$. Finally, the reduced suspensions were filtered and successively washed with an excess of distilled water and stored at $4^{\circ} \mathrm{C}$.

\section{Metal-Chelated Agarose}

$\mathrm{Ag}-\mathrm{Ni}^{2+}$ was prepared as previously described by Mateo et al. [2010]. Briefly, the epoxy groups of glyoxyl-agarose activated with epichlorohydrin, as described above, were partially hydrolyzed with $0.1 \mathrm{M}$ of $\mathrm{H}_{2} \mathrm{SO}_{4}$ at $\mathrm{pH} 2.0$ for $8 \mathrm{~h}$. The remaining epoxy groups were incubated with $0.1 \mathrm{M}$ of sodium iminodiacetate at $\mathrm{pH} 11.0$ for $24 \mathrm{~h}$ at $25^{\circ} \mathrm{C}$. Finally, the support was incubated with $0.23 \mathrm{M}$ of $\mathrm{NiCl}_{2}$ at $\mathrm{pH} 7.0$ for $24 \mathrm{~h}$ at $25^{\circ} \mathrm{C}$.

$\alpha R \beta G l$ Immobilization on Different Agarose-Type Matrices

Ten milliliters of enzyme solution $(0.14 \mathrm{U} / \mathrm{ml})$ at the indicated $\mathrm{pH}$ and conditions were mixed with $1 \mathrm{~g}$ of different activated supports. The immobilization course and the expressed activities were monitored measuring the enzyme activity in the supernatant and the suspension at different time points. Under all im- 
mobilization conditions, a blank assay was carried out with inert agarose.

The conditions used to immobilize $\alpha \mathrm{R} \beta \mathrm{Gl}$ on $\mathrm{Ag}-\mathrm{CB}, \mathrm{Ag}-\mathrm{A}$, Ag-PEI and $\mathrm{Ag}-\mathrm{Ni}^{2+}$ were $25 \mathrm{mM}$ of phosphate buffer at $\mathrm{pH} 7$ and $25^{\circ} \mathrm{C}$. In the case of immobilization on $\mathrm{Ag}-\mathrm{G}$, the immobilization needed to be carried out in $100 \mathrm{mM}$ of sodium carbonate ( $\mathrm{pH} 10.0)$ for $24 \mathrm{~h}$ at $25^{\circ} \mathrm{C}$. These latter derivatives were finally reduced using $1 \mathrm{mg} / \mathrm{ml}$ of $\mathrm{NaBH}_{4}$ solution to turn the reversible Schiff s base into an irreversible secondary amine. $\alpha \mathrm{R} \beta \mathrm{Gl}$ immobilized on $\mathrm{Ag}-\mathrm{A}$ and Ag-PEI were further cross-linked using glutaraldehyde. One gram of the immobilized enzyme preparation was suspended in $10 \mathrm{ml}$ of $0.5 \% \mathrm{v} / \mathrm{v}$ glutaraldehyde in $25 \mathrm{mM}$ of sodium phosphate buffer, $\mathrm{pH}$ 7.0. The suspension was kept under mild stirring at $25^{\circ} \mathrm{C}$ for $1 \mathrm{~h}$. Then, the cross-linked derivative was filtered and washed exhaustively with $25 \mathrm{mM}$ of sodium phosphate buffer at $\mathrm{pH}$ 7.0.

The immobilization yield (YI) and the immobilization efficiency (EI) were defined as:

$$
\begin{aligned}
& Y I=\frac{A_{\text {loaded }}-A_{\text {unbound }}}{A_{\text {loaded }}} \times 100 \\
& E I=\frac{A_{\text {beads }}}{A_{\text {loaded }}-A_{\text {unbound }}} \times 100
\end{aligned}
$$

where $A_{\text {loaded }}$ is the enzyme activity loaded, $A_{\text {unbound }}$ is the enzyme activity remaining in the supernatant, and the activity bound to the support $\left(A_{\text {beads }}\right)$ was calculated as the units of enzyme activity per gram of wet beads.

\section{Enzymatic Activity Assays}

$\alpha \mathrm{R} \beta \mathrm{Gl}$ activity was quantified by measuring the increase in absorbance at $323 \mathrm{~nm}$ caused by the release of hesperetin during the hydrolysis of the substrate $(0.1 \mathrm{~mm}$ hesperidin in $50 \mathrm{~mm}$ Tris- $\mathrm{HCl}$ buffer, pH 8.0) [Mazzaferro and Breccia, 2012]. The reactions were performed under continuous magnetic stirring at $50^{\circ} \mathrm{C}$. One unit of $\alpha \mathrm{R} \beta \mathrm{Gl}$ was defined as the amount of enzyme required to release $1 \mu \mathrm{mol}$ of hesperetin per minute.
Stability Assays

The stability of different enzyme derivatives was assessed by incubating the preparations with $50 \% \mathrm{v} / \mathrm{v}$ DMSO solution at different temperatures. Samples of the suspension were withdrawn at different times, and residual activity was expressed as a percentage of the initial activity. The inactivation rate followed first-order kinetics; therefore, a nonlinear fitting using a single exponential decay model was performed [Yoon and McKenzie, 2005]:

$$
[A]_{t}=[A]_{O} \exp (-k t)
$$

where $[A]_{t}$ is the percentage enzyme activity at time $\mathrm{t}(\mathrm{h}),[A]_{O}$ is the initial percentage activity, and $k$ the first order rate constant $\left(h^{-1}\right)$. The half-life $\left(t_{1 / 2}\right)$ of the preparation was calculated as $0.693 / \mathrm{k}$ as an index of stability.

\section{Production of Hesperetin}

The process of hesperetin production was evaluated using the selected immobilized preparation in different reaction media. Substrate concentration was assessed in the range of $0.50-15 \mathrm{mM}$ of hesperidin. The effect of solvent concentration and temperature was performed in solutions between 10 and $70 \% \mathrm{v} / \mathrm{v}$ DMSO in $50 \mathrm{mM}$ of sodium citrate at $\mathrm{pH} 5.0$, and between 25 and $60^{\circ} \mathrm{C}$, respectively. The quantification of the rendered hesperetin was performed using the method recently reported by Mazzaferro and Breccia [2012].

\section{Acknowledgments}

Financial support from the Spanish Ministry of Science (Programa Juan de la Cierva), Consejo Nacional de Investigaciones Científicas y Técnicas (CONICET), Universidad Nacional de La Pampa, Agencia Nacional de Promoción Científica y Tecnológica is gratefully acknowledged. We would also specially like to acknowledge the Fundación Carolina.

\section{References}

Arakawa T, Kita Y, Timasheff SN: Protein precipitation and denaturation by dimethyl sulfoxide. Biophys Chem 2007;131:62-70.

Benavente-García O, Castillo J, Marin FR, Ortuño A, Del Río JA: Uses and properties of citrus flavonoids. J Agric Food Chem 1997;45:45054515.

-Chang HY, Lee YB, Bae HA, Huh IY, Nam SH, Sohn HS, Lee HJ, Lee SB: Purification and characterization of Aspergillus sojae naringinase: the production of prunin exhibiting markedly enhanced solubility with in vitro inhibition of HMG-CoA reductase. J Agric Food Chem 2011;124:234-241.

-Di Majo D, Giammanco M, La Guardia M, Tripoli E, Giammanco S, Finotti E: Flavanones in citrus fruit: structure-antioxidant activity relationships. Food Res Int 2005;38:1161-1166.

-Ellenrieder G, Blanco S, Daz M: Hydrolysis of supersaturated naringin solutions by free and immobilized naringinase. Biotechnol Tech 1998;12:63-65.

-Fernandez-Lafuente R, Rosell CM, Rodriguez V, Santana C, Soler G, Bastida A, Guisan JM: Preparation of activated supports containing low $\mathrm{pK}$ amino groups: a new tool for protein immobilization via the carboxyl coupling method. Enzyme Microb Technol 1993;15: 546-550.

Genovés S, Gil JV, Vallés S, Casas JA, Manzanares P: Assessment of the aromatic potential of palomino fino grape must using glycosidases. Am J Enol Viticult 2005;56:188-191.

-Guisán J: Aldehyde-agarose gels as activated supports for immobilization-stabilization of enzymes. Enzyme Microb Technol 1988; 10: 375-382.

Hemingway KM, Alston MJ, Chappell CG, Taylor AJ: Carbohydrate-flavour conjugates in wine. Carbohydr Polym 1999;38:283-286.
Henley JP, Sadana A: Deactivation theory. Biotechnol Bioeng 1986;28:1277-1285.

Mandalari G, Bennett RN, Kirby AR, Lo Curto RB, Bisignano G, Waldron KW, Faulds CB: Enzymatic hydrolysis of flavonoids and pectic oligosaccharides from Bergamot (Citrus bergamia Risso) peel. J Agric Food Chem 2006; 54:8307-8313.

Manthey JA, Grohmann K: Concentrations of hesperidin and other orange peel flavonoids in citrus processing byproducts. J Agric Food Chem 1996;44:811-814.

Mateo C, Abian O, Bernedo M, Cuenca E, Fuentes M, Fernandez-Lorente G, Palomo JM, Grazu V, Pessela BCC, Giacomini C, Irazoqui G, Villarino A, Ovsejevi K, Batista-Viera F, Fernandez-Lafuente R, Guisan JM: Some special features of glyoxyl supports to immobilize proteins. Enzyme Microb Technol 2005;37: 456-462. 
Mateo C, Bolivar JM, Godoy CA, Rocha-Martin J, Pessela BC, Curiel JA, Muñoz R, Guisan JM, Fernandez-Lorente G: Improvement of enzyme properties with a two-step immobilizaton process on novel heterofunctional supports. Biomacromolecules 2010;11:31123117.

Mateo C, Palomo JM, Fuentes M, Betancor L, Grazu V, López-Gallego F, et al: Glyoxyl agarose: a fully inert and hydrophilic support for immobilization and high stabilization of proteins. Enzyme Microb Technol 2006;39:274280.

Mazzaferro LS, Breccia JD: Functional and biotechnological insights into diglycosidases. Biocatalysis Biotransform 2011;29:103-112.

Mazzaferro LS, Breccia JD: Quantification of hesperidin in citrus-based foods using a fungal diglycosidase. Food Chem 2012; 134: 23382344.

Mazzaferro LS, Piñuel L, Erra-Balsells R, Giudicessi SL, Breccia JD: Transglycosylation specificity of Acremonium sp. $\alpha$-rhamnosyl- $\beta$ glucosidase and its application to the synthesis of the new fluorogenic substrate 4-methylumbelliferyl-rutinoside. Carbohydr Res 2012;347:69-75.
Mazzaferro LS, Piñuel L, Minig M, Breccia JD: Extracellular monoenzyme deglycosylation system of 7-O-linked flavonoid $\beta$-rutinosides and its disaccharide transglycosylation activity from Stilbella fimetaria. Arch Microbiol 2010;192:383-393, erratum in Arch Microbiol 2011;193:461.

Nam HK, Hong SH, Shin KC, Oh DK: Quercetin production from rutin by a thermostable $\beta$-rutinosidase from Pyrococcus furiosus. Biotechnol Lett 2012;34:483-489.

Orrillo AG, Ledesma P, Delgado OD, Spagna G, Breccia JD: Cold-active $a$-L-rhamnosidase from psychrotolerant bacteria isolated from a sub-Antarctic ecosystem. Enzyme Microb Technol 2007;40:236-241.

Pedroche J, Yust MM, Mateo C, Fernández-Lafuente R, Girón-Calle J, Alaiz M, Vioque J, Guisán JM, Millán F. Effect of the support and experimental conditions in the intensity of the multipoint covalent attachment of proteins on glyoxyl-agarose supports: correlation between enzyme-support linkages and thermal stability. Enzyme Microb Technol 2007; 40:1160-1166.

Piñuel L, Mazzaferro LS, Breccia JD: Operational stabilization of fungal $\alpha$-rhamnosyl- $\beta$ glucosidase by immobilization on chitosan composites. Process Biochem 2011;46:2330 2335.

Reshmi R, Sugunan S: Improved biochemical characteristics of cross-linked $\beta$-glucosidase on nanoporous silica foams. J Mol Catal B: Enzym 2012;85-86:111-118.
Ribeiro MH: Naringinases: occurrence, characteristics, and applications. Appl Microbiol Biotechnol 2011;90:1883-1895.

-Scaroni E, Cuevas C, Carrillo L, Ellenrieder G: Hydrolytic properties of crude $\alpha$-Lrhamnosidases produced by several wild strains of mesophilic fungi. Lett Appl Microbiol 2002;34:461-465.

Sheldon RA: Enzyme immobilization: the quest for optimum performance. Adv Synth Catal 2007;349:1289-1307.

- Spagna G, Barbagallo RN, Greco E, Manenti I, Pifferi PG: A mixture of purified glycosidases from Aspergillus niger for oenological application immobilized by inclusion in chitosan gels. Enzyme Microb Technol 2002;30:80-89.

-Wang D, Kurasawa E, Yamaguchi Y, Kubota K, Kobayashi A: Analysis of glycosidically bound aroma precursors in tea leaves. II. Changes in glycoside contents and glycosidase activities in tea leaves during the black tea manufacturing process. J Agric Food Chem 2001;49: 1900-1903.

Yoon JH, McKenzie D: A comparison of the activities of three $\beta$-galactosidases in aqueousorganic solvent mixtures. Enzyme Microb Technol 2005;36:439-446. 